\title{
PRELIMINARY RESULTS OF VERTEBRAL CANAL DECOMPRESSION BY SPINOUS PROCESS SPLITTING
}

\author{
RESULTADOS PRELIMINARES DA DESCOMPRESSÃO DO CANAL VERTEBRAL \\ POR SEPARAÇÃO DO PROCESSO ESPINHOSO
}

\section{RESULTADOS PRELIMINARES DE LA DESCOMPRESIÓN DEL CANAL VERTEBRAL POR SEPARACIÓN DEL PROCESO ESPINOSO}

\author{
Thiago Dantas Matos, ${ }^{1}$ Yony Osorio Garcia, ${ }^{1}$ Herton Rodrigo Tavares Costa, ${ }^{1}$ Helton luiz Aparecido Defino \\ 1. Universidade de São Paulo, Faculdade de Medicina de Ribeirão Preto, Hospital das Clínicas, Department of Biomechanics, Medicine, and Rehabilitation of the Locomotor Apparatus \\ - HCRP-FMRP-USP, Ribeirão Preto, SP, Brazil.
}

\begin{abstract}
Objective: Considering that the technique of spinous process splitting has been advocated as a less invasive treatment of lumbar stenosis, the objective of this study was to evaluate the preliminary results of this technique in the surgical treatment of lumbar canal stenosis. Methods: Twenty patients with lumbar spinal canal stenosis who underwent surgical treatment for lumbar canal decompression with the spinous process splitting technique were assessed in the preoperative period and on postoperative days 1, 7 and 30 for VAS for lower back and lower limbs pain and radiographic evaluation of the operated segment. Results: The mean visual analogue scale score for lumbar pain in the preoperative assessment was $4.2 \pm 3.37$ and $0.85 \pm 0.88,1.05 \pm 1.19$ and $1.15 \pm 1.04$ after 1,7 and 30 postoperative days, respectively. The mean VAS score for lower limb pain was $8 \pm 1.72$ preoperatively, and $0.7 \pm 1.13,0.85 \pm 1.04$, and $1.05 \pm 1$ after 1,7 , and 30 postoperative days, respectively. There were no radiographic signs of instability of the vertebral segment operated in the radiographic evaluation. Conclusions: Decompression of the lumbar canal through the spinous process splitting technique in patients with lumbar canal stenosis had good immediate and short-term results in relation to low back and lower limbs pain. Level of evidence IV; Therapeutic Study.
\end{abstract}

Keywords: Spinal Stenosis; Low Back Pain; Laminectomy.

\section{RESUMO}

Objetivo: A técnica da separação do processo espinhoso tem sido preconizada como técnica menos invasiva para o tratamento da estenose lombar. Objetivo é avaliar os resultados preliminares dessa técnica no tratamento cirúrgico da estenose do canal lombar. Métodos: Vinte pacientes portadores de estenose do canal vertebral lombar e submetidos ao tratamento cirúrgico para descompressão do canal lombar, por meio da técnica da separação do processo espinhoso, foram avaliados no período pré-operatório, um, sete e trinta dias de pós-operatório, por meio da escala visual de avaliação da dor lombar e dor nos membros inferiores e avaliação radiográfica do segmento operado. Resultados: O escore médio da escala visual analógica da dor lombar na avaliação pré-operatória foi 4,2 \pm 3,37 e, respectivamente, 0,85 \pm 0,88; 1,05 \pm 1,19 e 1,15 \pm 1,04 após um, sete e trinta dias de pós-operatório. O escore médio da escala visual analógica da dor nos membros inferiores foi $8 \pm 1,72$ no pré-operatório e, respectivamente, 0,7 \pm 1,13; 0,85 $\pm 1,04$ e 1,05 \pm 1 após um, sete e trinta dias de pós-operatório. Não foram observados sinais radiográficos de instabilidade do segmento vertebral operado na avaliação radiográfica. Conclusão: A descompressão do canal lombar por meio da técnica da separação do processo espinhoso nos pacientes com estenose do canal lombar apresentou bons resultados imediatos e a curto prazo, em relação à dor lombar e dor nos membros inferiores. Nível de evidência IV; Estudo Terapêutico.

Descritores: Estenose Espinhal; Dor Lombar; Laminectomia.

\section{RESUMEN}

Objetivo: Teniendo en cuenta que la técnica de separación del proceso espinoso ha sido recomendada para el tratamiento menos invasivo de la estenosis lumbar, el objetivo de este estudio fue evaluar los resultados preliminares de esta técnica en el tratamiento quirúrgico de la estenosis del canal lumbar. Métodos: Veinte pacientes con estenosis del canal espinal lumbar que se sometieron a tratamiento quirúrgico para descompresión del canal lumbar con la técnica de separación del proceso espinoso se evaluaron en el período preoperatorio y en los días 1, 7 y 30 postoperatorios mediante EVA para del dolor lumbar y de los miembros inferiores y evaluación radiográfica del segmento operado. Resultados: La puntuación promedio de la escala visual analógica del dolor lumbar en la evaluación preoperatoria fue de 4,2 $\pm 3,37$ y $0,85 \pm 0,88 ; 1,05 \pm 1,19$ y $1,15 \pm 1,04$ después de 1,7 y 30 días postoperatorios. La puntuación promedio de la EVA para el dolor de las extremidades inferiores fue $8 \pm 1,72$ en el preoperatorio y de 0,7 $\pm 1,13 ; 0,85 \pm 1,04$ y 1,05 \pm 1 después de 1, 7 y 30 días postoperatorios, respectivamente. No se observaron signos radiográficos de inestabilidad del segmento vertebral operado en la evaluación radiográfica. Conclusiones: La descompresión del canal lumbar por medio de la técnica de separación del proceso espinoso en pacientes con estenosis del canal lumbar tuvo buenos resultados inmediatos y a corto plazo con relación al dolor lumbar y las extremidades inferiores. Nivel de evidencia IV; Estudio Terapéutico.

Descriptores: Estenosis Espinal; Dolor de la Región Lumbar; Laminectomía.

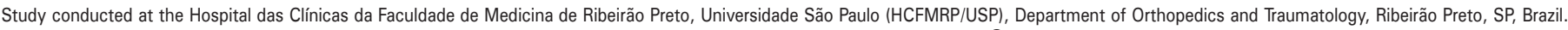
Correspondence: Thiago Dantas Matos. Rua Florêncio de Abreu, 1201, Ap 102, Ribeirão Preto, SP, Brasil. 14015-060. Tdmatos@yahoo.com.br 


\section{INTRODUCTION}

Degenerative changes of the vertebral segment causing compression of the nerve structures inside the vertebral canal and vertebral foramen were identified long ago and reported before lumbar disc herniation. ${ }^{1}$

The surgical treatment of lumbar canal stenosis has been performed by means of decompression of the nerve structures of the affected vertebral segment. Classically, decompression of the nerve structures has been accomplished by removal of the lamina, facet joints, ligamentum flavum, and osteophytes of the canal and vertebral foramen. ${ }^{2,3}$ Laminoplasty has also been performed as an alternative for decompression of the nerve structures and to preserve the continuity of the posterior vertebral elements (spinous process and vertebral lamina). ${ }^{4}$ Decompression has been classically performed by exposing the posterior vertebral elements. This surgical approach promotes the detachment and retraction of the paravertebral muscles and the morbidity related to the injury to the paravertebral muscles caused by ischemia, denervation, and muscle detachment has motivated the development of less invasive surgical techniques. ${ }^{2}$

Preservation of the paravertebral muscles has been the objective of several techniques that have been described for decompression of the vertebral canal. The technique of longitudinal splitting of the spinous process at the midline to preserve the paravertebral muscles during lumbar spine decompression was described by Watanabe et al. in 2005. ${ }^{3,5}$ The approach by means of the splitting the spinous process preserves the insertion of the multifidus muscles and reduces the damage to the paravertebral musculature that occurs in the classical open approach. ${ }^{4,6}$

Performing less invasive surgeries with lower morbidity has been one of the goals of modern spine surgery and the spinous process splitting technique has been highlighted for its technical simplicity and reports of good results from its application. ${ }^{3,7}$

The objective of this study was to observe the preliminary clinical and radiographical results from the use of the technique of spinal canal decompression by means of the approach using longitudinal splitting of the spinous process in patients with spinal canal stenosis.

\section{METHODS}

This was a prospective observational study of a group of patients from the same institution with lumbar canal stenosis who underwent surgical treatment by means of lumbar canal decompression using the spinous process splitting technique. The study was approved by the HCFMRP-USP Institutional Review Board (CAAE: 91173618.9.0000.5440) and the patients signed the Informed Consent Form.

Twenty patients with lumbar canal stenosis underwent surgical treatment using the spinous process splitting technique. ${ }^{5}$ Fourteen of the patients were male and six were female with ages ranging from 47 to 87 years (mean 68.18). The stenosis was located at one level in 16 patients, two levels in 3 patients, and three levels in 1 patient. Level L2-L3 was affected in 2 patients, L3-L4 in 4 patients, L4-L5 in 13 patients, and L5-S1 in 6 patients. (Figure 1)
The patients were evaluated by means of clinical and radiographical parameters. The visual analog scale for lumbar pain and pain in the lower limbs was evaluated in the preoperative period, the intermediate postoperative period, one week, and one month following surgery. The radiographical evaluation was performed from radiographs in AP and lateral incidences of the lumbar spine to detect changes (slippage of vertebrae, deviations or scoliosis in the frontal plane) that show postoperative instability of the vertebral segment.

The indication for surgical treatment was related to the presence of symptoms of lumbar canal stenosis (neurogenic claudication or symptoms of radicular compression) that were resistant to conservative treatment and interfered with the daily activities of the patients, and the absence of clinical and radiological signs showing instability of the vertebral segment with an indication of stabilization.

\section{Surgical technique}

The patients underwent general anesthesia and were positioned in ventral decubitus. By means of a medial incision over the spinous process of the affected vertebra, the spinous process was exposed and divided in the middle longitudinally up to its base with the assistance of a drill of around $2 \mathrm{~mm}$ in diameter. Then the base of the spinous process was sectioned with the aid of an osteotome and the base of the lamina exposed. The two parts of the spinous process were retracted for visualization of the base of the vertebral lamina, and thus, the insertion of the paravertebral muscle was preserved. (Figure 2)

After exposure of the vertebral lamina and removal of the ligamentum flavum, decompression was performed by means of a laminectomy and the removal of the medial portion of the facet joints and a foraminotomy according to the individual need for decompression of the affected nerve structures. (Figure 2) A discectomy was indicated only in patients who presented significant prolapse of the intervertebral disc with compression of the nerve root. The removal of the facet joint and vertebral foramen decompression were performed in order to preserve stability of the vertebral segment, avoiding excessive removal of the facet joints

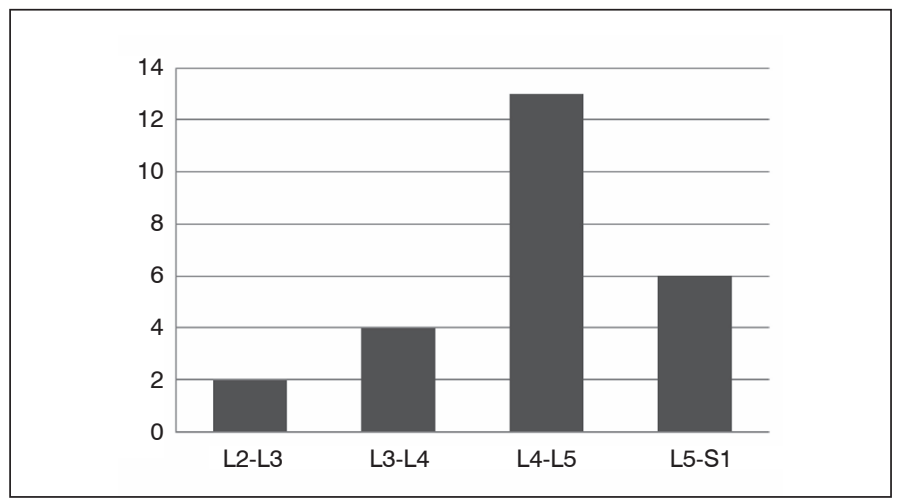

Figure 1. Distribution of patients with lumbar canal stenosis by location of the vertebral segment.

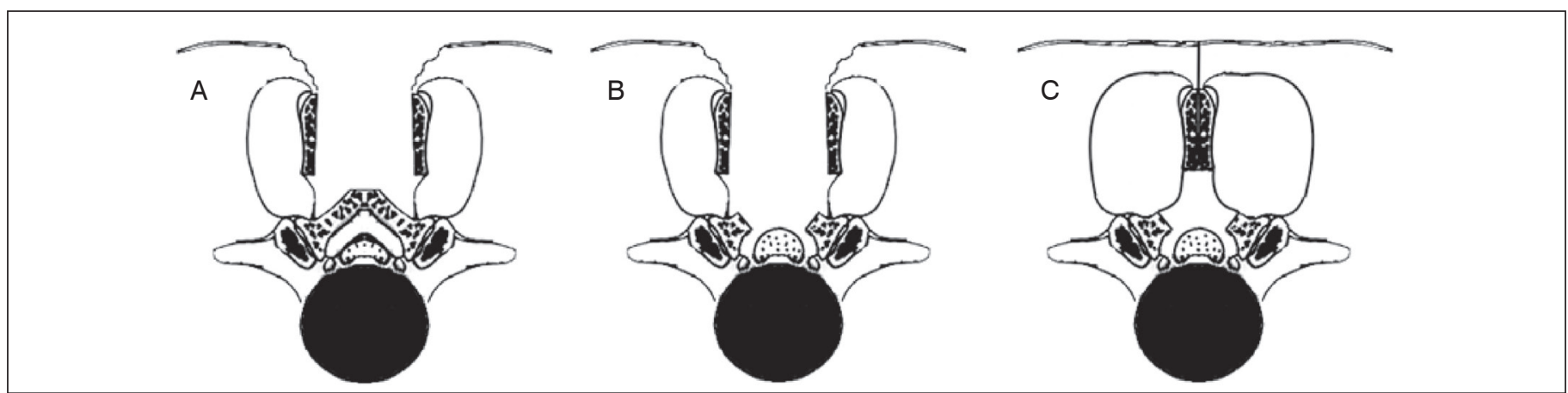

Figure 2. Illustration of the surgical technique: A- splitting of the spinous process and exposure of the base of the lamina, B- after the laminectomy and decompression of the canal, and C- after closure of the spinous process. 
After decompression and hemostasis, the separated parts of the spinous process were brought together and sutured by means of transfixing sutures.

Standard postoperative analgesia was administered to the patients, and they were mobilized and free to walk in accordance with their pain symptoms.

\section{Statistical study}

Descriptive statistical analysis of the evaluation score values (lumbar pain and pain in the lower limbs) was conducted. Because of the normality of the data, parametric analysis was performed with linear mixed effect models (random and fixed effects) to determine whether there was a statistical difference between VAS lumbar pain and VAS lower limb pain in the preoperative period, the immediate postoperative at 1 day (D1), after 7 days (D7), and after 30 days (D30). $P<0.05$ was defined as significant.

The SAS/STAT ${ }^{\circledR}$, Version 9.4 program (SAS Institute Inc., Cary, NC, 2012) was used for the statistical analyses.

\section{RESULTS}

All twenty patients were evaluated according the parameters (analog lumbar pain scale, analog lower member pain scale, lumbar spine radiographs in AP and lateral incidences) and the established evaluation periods: preoperative, 1,7 , and 30 days following surgery (Tables 1 and 2).

Table 1. Values of individual scores for lumbar pain and lower limb pain according to the visual analog scale in the evaluation periods.

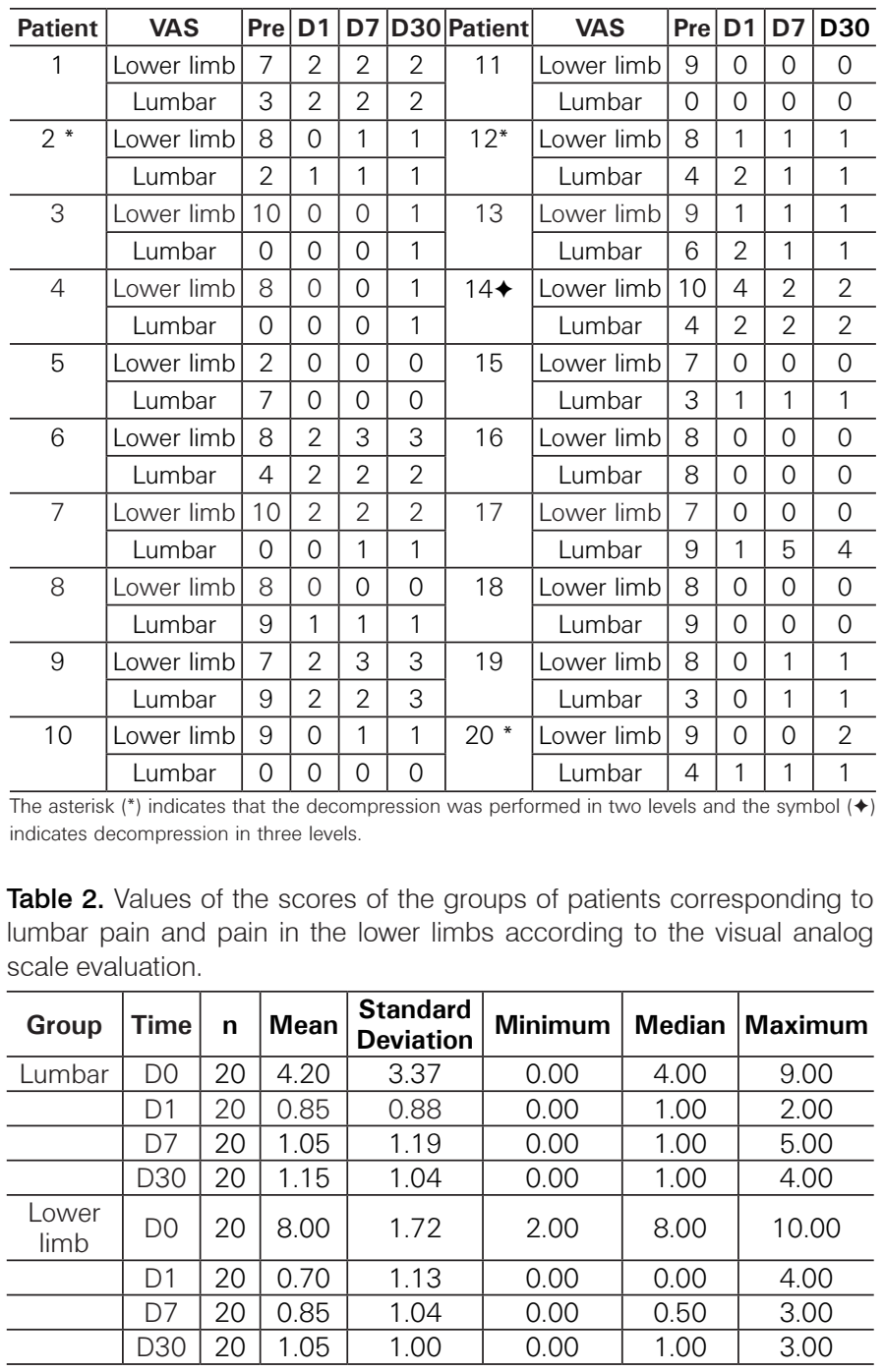

In the preoperative period, the values for lumbar pain according to the analog scale ranged from 0 to 9 (mean of $4.2 \pm 3.37$ ). In the postoperative period, the values ranged from 0 to 2 (mean $0.85 \pm 0.88$ ) after one day, from 0 to 5 (mean $1.05 \pm 1.19$ ) after one week, and from 0 to 4 (mean $1.15 \pm 1.04$ ) after one month. Statistically significant reductions in lumbar pain scores $(p<0.0001)$ were observed in the immediate postoperative period, at seven days, and at thirty days, when compared to the preoperative scores (Figure 3). There were no significant differences between the immediate postoperative, seven-day, and thirty-day values.

The assessment of pain in the lower limbs according to the analog evaluation scale presented preoperative values ranging from 0 to 9 (mean $8 \pm 1.72$ ). On the first day following surgery the values ranged from 0 to 4 (mean $0.7 \pm 1.13$ ), from 0 to 3 (mean $0.85 \pm 1.04$ ) after a week, and from 0 to 3 (mean $1.05 \pm 1$ ) after a month. A statistically significant reduction $(p<0.0001)$ was observed in the evaluation scores of pain in the lower limbs in the immediate postoperative, at seven days, and at thirty days as compared to the preoperative values. (Figure 3)

The lumbar and lower limb analog scale evaluation scores are shown by the number of levels (1,2, or 3 ) in which decompression was performed in Figures 4 and 5 . In the patients who underwent three-level decompression, a tendency towards higher score values as compared to patients who underwent decompression at 1 or 2 levels was observed, but it was not possible to evaluate the statistical significance due to the limited number of patients.

The radiographical evaluation at one month following surgery did not present any evidence of instability in the operated vertebral segment resulting from the procedure performed. The radiographic images did not show any alterations when compared with the preoperative images.

No postoperative complications were observed in the group of patients evaluated. All patients were able to walk and were discharged from the hospital on the first postoperative day.

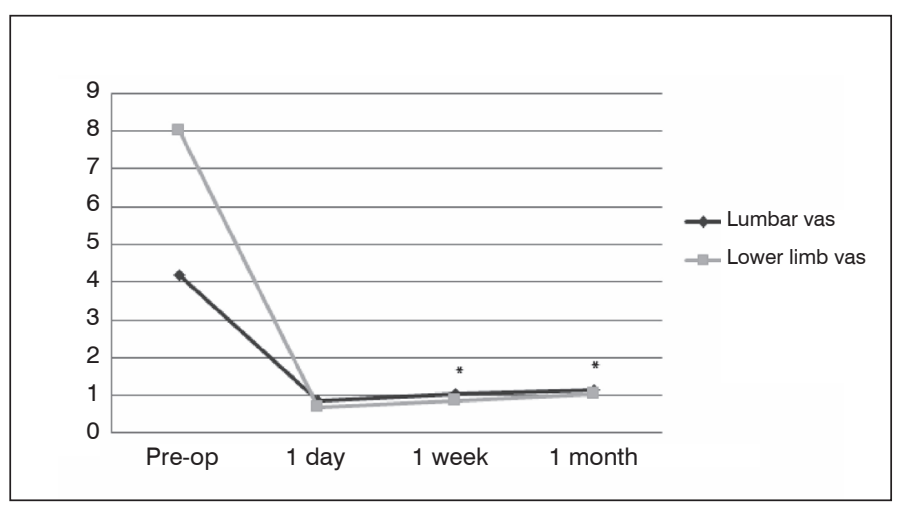

Figure 3. Values of lumbar and lower limb pain scores by evaluation period. The asterisk $\left(^{*}\right)$ indicates a statistical difference in relation to preoperative values.

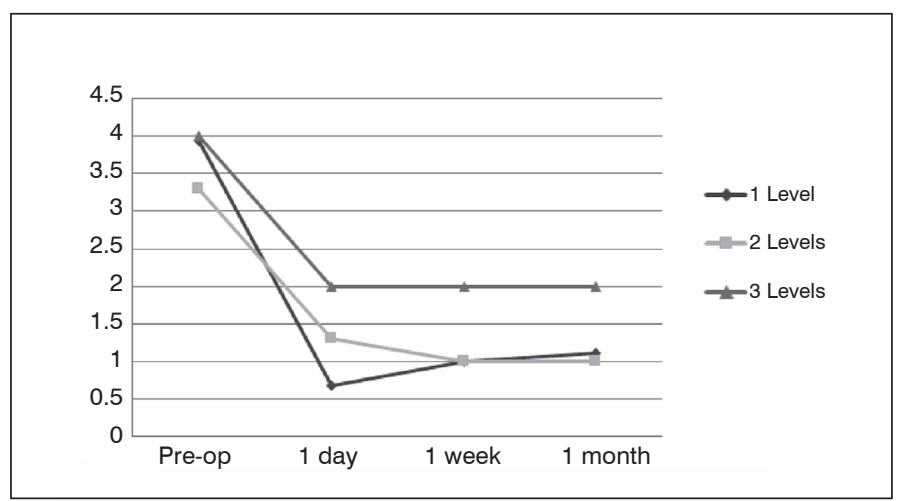

Figure 4. Values of the visual analog scale scores for lumbar pain by evaluation period. 


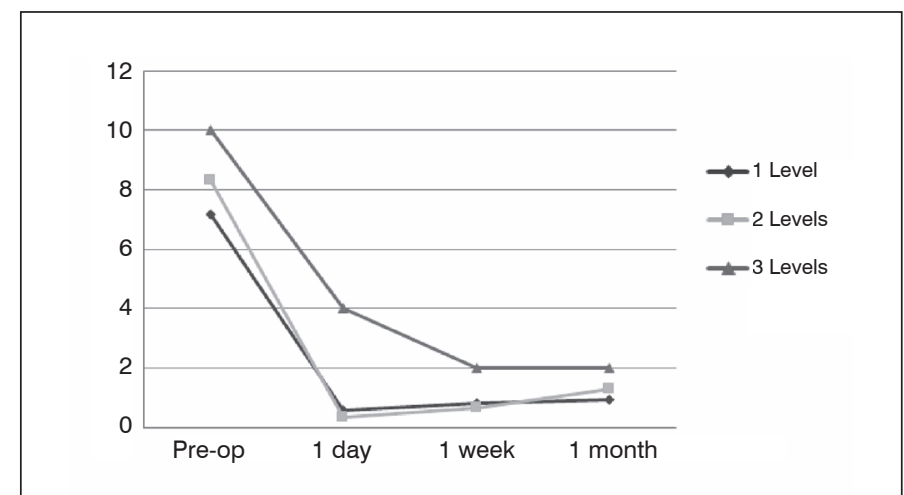

Figure 5. Values of the visual analog scale scores for lower limb pain by evaluation period

\section{DISCUSSION}

The use of decompression of the vertebral canal in patients with lumbar stenosis by means of the spinous process splitting technique resulted in significant reductions in the visual analog evaluation scores for lumbar and lower limb pain. Reduced lumbar and lower limb pain were observed in the immediate postoperative evaluation one day following surgery and were maintained in the evaluations conducted at seven and thirty days following surgery. There was a proportionally greater reduction of pain in the lower limbs after decompression of the nerve structures using this technique. The assessment performed indicated only the preliminary short-term results, evidencing the effectiveness of the decompression achieved by the technique used. We do not have long-term follow-up information, but the results reported in the literature have been very favorable and stimulated the introduction of this technique into our field of activity. 2,3,7,8

The efficacy of the surgical treatment of lumbar canal stenosis has been well-evidenced in prospective, randomized studies ${ }^{9,10}$ and it has been established that decompression of the vertebral canal, lateral recess, and vertebral foramen promote the improvement of symptoms. However, there are potential risks arising from the conventional surgical procedure involving open dissection with displacement and retraction of the paravertebral muscles, resection of the vertebral lamina, facet joints, spinous process, and injury to the posterior ligament structures. ${ }^{11-16}$ Alternative surgical techniques have been developed aimed at overcoming the complications resulting from the removal and injury of the posterior vertebral elements. ${ }^{4}$ The spinous process splitting technique was described by Watanabe in 2005 to avoid the complications associated with the removal and displacement of posterior vertebral elements and good results have been reported with its use. ${ }^{3,5}$

The spinous process splitting technique is considered a less invasive approach to the lumbar spine and avoids iatrogenic instability as compared to the conventional open approach. ${ }^{6,17}$ This technique reduces the injury to the paravertebral muscles and preserves the insertion of the multifidus muscles into the spinous process. ${ }^{4}$ In an experimental study using rabbits, it was observed that the disinsertion of the multifidus muscle is an important cause of muscular atrophy and consequent chronic pain. ${ }^{18}$
The integrity of the posterior elements and continuity between the spinous process and the vertebral lamina has been correlated with good long-term results ${ }^{4}$ and new decompression techniques recommending laminoplasty have been described with good results for the treatment of stenosis of the vertebral canal. These techniques use the split spinous process approach and perform laminoplasty to enlarge the vertebral canal. ${ }^{4}$

Postoperative instability has been reported in around $3-20 \%$ of patients in long-term follow-up. ${ }^{19-21}$ Although we did not observe instability in the radiographical evaluation of the operated segments, the follow-up period for the series of patients studied is very short. It should also be taken into account that instability is a dynamic process that may not be detected in simple radiographs. The evaluation period and the methodology used to assess instability in the group of patients studied must considered and do not support general conclusions. However, reports of case series with long follow-up periods have shown lower rates of vertebral segment instability with the spinous process splitting technique. ${ }^{2}$

The clinical parameters chosen for the preliminary evaluation of the group of patients studied were lumbar and lower limb pain, considering that these symptoms may be presented in different types of lumbar stenosis (central, lateral recess, or foraminal). ${ }^{9}$ The use of specific questionnaires might better assess the function of operated patients, but because of the short evaluation period only lumbar and lower limb pain were selected. The evaluation of pain has been criticized for the existence of a wide range of patient tolerance and perception. ${ }^{22,23}$ The postoperative recovery of the patients was satisfactory and they were all discharged on the first day following surgery. In a randomized study, Watanabe et al. (2011) observed less postoperative pain intensity in patients submitted to the spinous process splitting technique as compared to traditional open surgery. ${ }^{2,3,8}$

Lumbar vertebral canal decompression via the spinous process splitting technique permits wide exposure for decompression of the vertebral canal structures, the lateral recess, and the vertebral foramen, comparable to open exposure with bleeding and injury to the paravertebral musculature. The preliminary results using this technique, considering the parameters evaluated and patient recovery, were highly satisfactory and we expect that the good results will remain during late patient follow-up and evaluation.

\section{CONCLUSION}

The decompression of lumbar canal stenosis by means of the spinous process splitting technique yielded good results from the short-term evaluation of lumbar and lower limb pain in patients with lumbar canal stenosis. We observed reduction in the scores of the visual scale for lumbar pain and lower limb pain in the one-, sevenand thirty-day postoperative evaluations. There were no radiographical changes indicating instability of the operated segments.

All authors declare no potential conflict of interest related to this article.

CONTRIBUTION OF THE AUTHORS: Each author made significant individual contributions to this manuscript. TDM (0000-0003-3853-502X)*: surgery, writing, review, data analysis, statistical analysis. YOG (0000-0002-5927-5864): data collection, intellectual concept, review. HRTC (0000-0003-3965-6886)*. surgery, data analysis, writing. HLAD (0000-0003-4274-0130)*: surgery, data analysis, writing, review, intellectual concept. ${ }^{*}$ ORCID (Open Researcher and Contributor ID)

\section{REFERENCES}

1. Ehni GH. Spondylotic caudal radiculopathy and its effects on the nervous system. In: Weinstein PR. Lumbar spondylosis: Diagnosis, management, and surgical treatment. Baltimore: Year Book Med. Publ; 1977

2. Uehara M, Takahashi J, Hashidate H, Mukaiyama K, Kuraishi S, Shimizu M, et al. Comparison of Spinous Process-Splitting Laminectomy versus Conventional Laminectomy for Lumbar Spinal Stenosis. Asian Spine J. 2014;8(6):768-76.

3. Watanabe K, Matsumoto M, Ikegami T, Nishiwaki Y, Tsuji T, Ishii K, et al. Reduced posto- perative wound pain after lumbar spinous process-splitting laminectomy for lumbar canal stenosis: a randomized controlled study. J Neurosurg Spine. 2011:14(1):51-8.

4. Kakiuchi M, Fukushima W. Impact of Spinous Process Integrity on Ten to Twelve-Year Outcomes After Posterior Decompression for Lumbar Spinal Stenosis: Study of Open-Door Laminoplasty Using a Spinous Process-Splitting Approach. J Bone Joint Surg Am. 2015;97(20):1667-77.

5. Watanabe K, Hosoya T, Shiraishi T, Matsumoto M, Chiba K, Toyama Y. Lumbar spinous process-splitting laminectomy for lumbar canal stenosis. Technical note. J Neurosurg Spine. 2005:3(5):405-8. 
6. Kim K, Isu T, Sugawara A, Matsumoto R, Isobe M. Comparison of the effect of 3 different approaches to the lumbar spinal canal on postoperative paraspinal muscle damage. Surg Neurol. 2008;69(2):109-13; discussion 13.

7. Kanbara S, Yukawa Y, Ito K, Machino M, Kato F. Surgical outcomes of modified lumbar spinous process-splitting laminectomy for lumbar spinal stenosis. J Neurosurg Spine. 2015;22(4):353-7.

8. Lee S, Srikantha U. Spinous Process splitting Laminectomy: Clinical outcome and Radiological analysis of extent of decompression. Int J Spine Surg. 2015;9:20.

9. Weinstein JN, Tosteson TD, Lurie JD, Tosteson AN, Blood E, Hanscom B, et al. Surgical versus nonsurgical therapy for lumbar spinal stenosis. N Engl J Med. 2008;358(8):794-810.

10. Lurie JD, Tosteson TD, Tosteson A, Abdu WA, Zhao W, Morgan TS, et al. Long-term outcomes of lumbar spinal stenosis: eight-year results of the Spine Patient Outcomes Research Trial (SPORT). Spine (Phila Pa 1976). 2015;40(2):63-76.

11. Kawaguchi Y, Matsui H, Gejo R, Tsuji H. Preventive measures of back muscle injury after posterior lumbar spine surgery in rats. Spine (Phila Pa 1976). 1998;23(21):2282-7; discussion 8

12. Kawaguchi $Y$, Matsui $H$, Tsuji $H$. Back muscle injury after posterior lumbar spine surgery. $A$ histologic and enzymatic analysis. Spine (Phila Pa 1976). 1996;21(8):941-4.

13. Kawaguchi $Y$, Matsui $H$, Tsuji H. Back muscle injury after posterior lumbar spine surgery. Part 1: Histologic and histochemical analyses in rats. Spine (Phila Pa 1976). 1994;19(22):2590-7.

14. Kawaguchi Y, Yabuki S, Styf J, Olmarker K, Rydevik B, Matsui H, et al. Back muscle injury after posterior lumbar spine surgery. Topographic evaluation of intramuscular pressure and blood flow in the porcine back muscle during surgery. Spine (Phila Pa 1976). $1996 ; 21(22): 2683-8$
15. Mayer TG, Vanharanta H, Gatchel RJ, Mooney V, Barnes D, Judge L, et al. Comparison of CT scan muscle measurements and isokinetic trunk strength in postoperative patients. Spine (Phila Pa 1976). 1989;14(1):33-6.

16. See $\mathrm{DH}, \mathrm{Kraft} \mathrm{GH}$. Electromyography in paraspinal muscles following surgery for root compression. Arch Phys Med Rehabil. 1975;56(2):80-3

17. Maruo K, Tachibana T, Inoue S, Arizumi F, Yoshiya S. Prognostic Factors of Surgical Outcome after Spinous Process-Splitting Laminectomy for Lumbar Spinal Stenosis. Asian Spine J. 2015;9(5):705-12.

18. Hu ZJ, Fang XQ, Zhou ZJ, Wang JY, Zhao FD, Fan SW. Effect and possible mechanism of muscle-splitting approach on multifidus muscle injury and atrophy after posterior lumbar spine surgery. J Bone Joint Surg Am. 2013;95(24):e192(1-9).

19. Jönsson B, Annertz M, Sjöberg C, Strömqvist B. A prospective and consecutive study of surgically treated lumbar spinal stenosis. Part II: Five-year follow-up by an independent observer. Spine (Phila Pa 1976). 1997;22(24):2938-44

20. Shenkin HA, Hash CJ. Spondylolisthesis after multiple bilateral laminectomies and facetectomies for lumbar spondylosis. Follow-up review. J Neurosurg. 1979;50(1):45-7.

21. Lee CK. Lumbar spinal instability (olisthesis) after extensive posterior spinal decompression Spine (Phila Pa 1976). 1983;8(4):429-33.

22. Budithi S, Dhawan R, Cattell A, Balain B, Jaffray D. Only walking matters-assessment following lumbar stenosis decompression. Eur Spine J. 2017;26(2):481-7.

23. Harland NJ, Dawkin MJ, Martin D. Relative utility of a visual analogue scale vs. a sixpoint Likert scale in the measurement of global subject outcome in patients with low back pain receiving physiotherapy. Physiotherapy. 2015;101(1):50-4. 